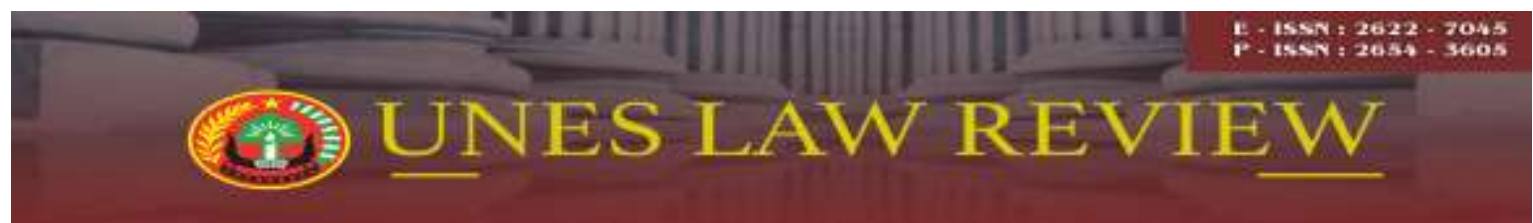

Email: uneslawreview@gmail.com

Online: http://review-unes.com/index.php/law

Volume 2, Issue 2, Desember 2019

\title{
TINJAUAN HAM TERHADAP PELAKSANAAN HUKUMAN RAJAM DI INDONESIA \\ (Studi Analisis Perbandingan Hukum Islam dan Hukum Nasional)
}

\author{
${ }^{1)}$ Fitra Mulyawan, ${ }^{2)}$ Wendriadi \\ ${ }^{1)}$ Dosen Fakultas Hukum, Universitas Ekasakti, Padang, Indonesia \\ E-mail : moelyaftr@yahoo.com \\ ${ }^{2)}$ Dosen Fakultas Hukum, Universitas Ekasakti, Padang, Indonesia \\ E-mail : awendri@yahoo.com
}

\begin{abstract}
ABSTRAK
HAM adalah hak kodrati yang dianugerahkan Allah SWT kepada setiap manusia dan tidak dapat dicabut atau dikurangi oleh kekuasaan atau badan apapun. Hak-hak yang diberikan Allah itu bersifat permanen, kekal dan abadi, tidak boleh diubah atau dimodifikasi. Dalam pandangan kasat mata, menunjukkan hukum pidana Islam sering terbentur dengan keadaan-keadaan yang sulit untuk didekati dengan hukum tersebut, baik itu berkaitan dengan HAM atau bahkan hukum yang dipegang oleh suatu negara. khususnya mengenai hudud seperti potong tangan bagi pencuri, hukum rajam bagi pezina, serta qishash, sering mendapat sorotan tajam dari berbagai kalangan. Oleh karena itu para fuqaha berbeda pendapat dalam penerapan hukuman rajam, sebagian fuqaha' setuju dengan hukuman rajam, dengan dasar hadis Nabi sebagai sandaran hukum. Namun sebagian Fuqaha' yang lain menyatakan tidak setuju dengan hukuman rajam, karena mereka mengganggap bahwa hadis tersebut tidak cukup sebagai dasar hukum. Dalam hukum nasional sangat jelas perbedaan antara hukum Islam dan hukum yang berlaku saat ini di Indonesia khususnya berkaitan dengan sanksi bagi pelaku zina muhshan. Ketentuan hukuman rajam berlawanan menurut pandangan HAM antara lain dengan: Deklarasi Umum HAM (DUHAM), Konvensi menentang penyiksaan dan perlakuan atau penghukuman lain yang kejam, tidak manusiawi dan merendahkan martabat manusia, dan Konvensi Hak Sipil dan Politik dan UUD 1945.
\end{abstract}

Kata Kunci: HAM, Pelaksanaan Hukuman Rajam, Hukum Islam, Hukum Nasional

\section{PENDAHULUAN}

Islam adalah agama universal yang mengajarkan keadilan bagi semua manusia tanpa pandang bulu. Ajaran Islam mengandung unsur-unsur keyakinan (akidah), ritual (ibadah) dan pergaulan sosial (mu'amalat). Dimensi akidah memuat ajaran tentang keimanan; dimensi ibadah memuat ajaran tentang mekanisme pengabdian manusia terhadap Allah; sedangkan dimensi mu'amalat memuat ajaran tentang hubungan manusia dengan sesama manusia dan dengan lingkungan sekitar. Seluruh unsur-unsur ajaran 
tersebut dilandasi oleh ketentuan-ketentuan yang disebut dengan istilah syari'at (fikih). Dalam konteks syari'at inilah terdapat ajaran tentang hak asasi manusia (HAM).

Sebagai agama kemanusiaan Islam meletakkan manusia pada posisi yang sangat mulia. Manusia digambarkan oleh al-Qur'an sebagai makhluk yang paling sempurna dan harus dimuliakan. Bersandar dari hal tersebut, perlindungan dan penghormatan terhadap HAM dalam Islam tidak lain merupakan tuntutan dari ajaran Islam yang wajib dilaksanakan oleh setiap pemeluknya. Penghormatan HAM dan bersikap adil terhadap manusia tanpa pandang bulu adalah esensi dari ajaran Islam. Dalam Islam sebagaimana dinyatakan oleh Abu A'la al-Maududi, HAM adalah hak kodrati yang dianugerahkan Allah SWT kepada setiap manusia dan tidak dapat dicabut atau dikurangi oleh kekuasaan atau badan apapun. Hak-hak yang diberikan Allah itu bersifat permanen, kekal dan abadi, tidak boleh diubah atau dimodifikasi.

Di dalam hukum pidana Islam (Jinayah) sangat diutamakan akan terciptanya perlindungan terhadap setiap individu manusia. Ketentuan pidana Islam, khususnya mengenai hudud seperti potong tangan bagi pencuri, hukum rajam bagi pezina, serta qishash, sering mendapat sorotan tajam dari berbagai kalangan. Ada juga yang menggambarkan hukuman tersebut sebagai suatu yang kejam dan melanggar HAM. Ketentuan-ketentuan hudud sifatnya memang mutlak (absolut), tetapi hudud mempunyai unsur dan syarat yang harus terpenuhi (Topo Santoso, 2003:11).

Pada dataran realita, menunjukkan hukum pidana Islam sering terbentur dengan keadaan-keadaan yang sulit untuk didekati dengan hukum tersebut, baik itu berkaitan dengan HAM atau bahkan hukum yang dipegang oleh suatu negara yang telah ditetapkan sebagai rujukan hukum bagi semua warga negara yang bersangkutan. Termasuk penilaianpenilaian yang dilontarkan beberapa kalangan, sehingga resistensi terhadap pemberlakuan hukum pidana Islam menjadi tambah besar.

Dalam kehidupan sehari-hari suatu perbuatan yang termasuk dalam kategori delik pidana sering muncul dan senantiasa menghiasi nuansa interaksisosial. Dalam hukum pidana Islam, melakukan perbuatan perzinahan merupakan suatu tindakan atau perbuatan yang benar-benar tercela dan termasuk dalam kategori dosa yang sangat besar.

Dengan demikian ancaman hukuman bagi pelaku perbuatan itu sangat berat, di dalam hukum Islam perbuatan seperti itu mendapat hukuman rajam dengan ditanam sampai leher 
kemudian dilempari pelaku dengan batu di hadapan orang banyak sampai mati, hukuman rajam itu hanya berlaku pada seseorang yang telah menikah dan melakukan perzinahan yang disebut zina mu.h.san, hukuman rajam sebenarnya sama dengan hukuman mati, hanya mungkin prosesinya saja yang berbeda. Sesuai dengan firman Allah dalam QS Annur ayat 2:

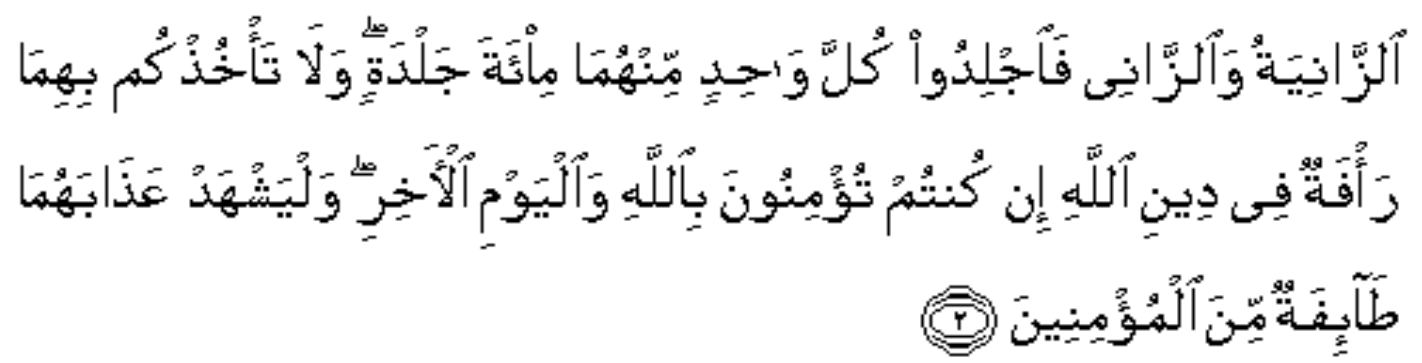

Artinya: Perempuan yang berzina dan laki-laki yang berzina, maka derahlah tiaptiap seseorang dari keduanya seratus kali dera, dan janganlah belas kasihan kepada keduanya mecegah kamu untuk menjalankan agama Allah, jika kamu beriman kepada Allah dan hari kiamat dan hendaklah pelaksanaan hukuman mereka disaksikan oleh sekumpulan orang-orang yang beriman (Departemen Agama RI, 2010: 488).

Dari ayat di atas dapat disimpulkan bahwa hukuman cambuk (dera) sebanyak seratus kali bagi pelaku zina ghairu muhshan, dan mengenai hukuman ini bersifat umum, tanpa memandang status dan golongan, akan tetapi mengenai hukuman rajam bagi pelaku zina muhshan hanya diketahui dari hadis rasululah saw.

Prof. Hamka dalam menanggapi masalah rajam yaitu menerima hukuman tersebut dengan alasan meskipun hukuman bagi pelaku zina mu.h.san tidak dijelaskan dalam ayatayat al-Qur'an, akan tetapi hal tersebut telah dilakukan oleh Rasulullah dan telah dijadikan sebagai sandaran hukum oleh perawi-perawi terpercaya.

Hukuman rajam dan persoalan kemanusian. Konsep perlindungan Hak Asasi Manusia (HAM) sangat di gombar-gombarkan saat ini, bahkan pada Negara yang notabene mayoritas Islam, sehingga konsep kemanusian tersebut dijadikan tolak ukur dalam setiap pembetukan Undang-undang. Banyak yang beranggapan bahwa sanksi yang terkandung dalam dalam pidana Islam sangatlah kejam dan tidak manusiawi, misalnya hukuman qishas yang dianggap sebagai bentuk pembalasan, hukuman potong tangan bagi pencuri, cambuk dan rajam bagi pelaku zina dan sebagainya. Dengan demikian mendorong penulis untuk menyoroti Hak Asasi Manusia dalam Penerapan Hukuman Rajam di Indonesia. 
Berdasar pada pemikiran tersebut maka permasalahan yang hendak dibahas akan dirumuskan sebagai berikut:

1. Bagaimana perbandingan hukum rajam dalam Islam dan hukum Nasional?

2. Bagaimana analisis perbandingan hukum rajam?

3. Bagaimana pandangan HAM terhadap hukum rajam?

\section{METODE PENELITIAN}

Metode penelitian yang telah digunakan adalah penelitian hukum empiris. Penelitian hukum empiris adalah penelitian hukum sosiologis yang dapat disbeut juga dengan penelitian lapangan.

\section{PEMBAHASAN DAN HASIL PENELITIAN}

\section{Hak Asasi Manusia}

Istilah hak asasi manusia dikenal dalam bahasa Prancis " Droits de l'homne, yang berarti "hak manusia', dalam bahasa Inggris disebut "Human rights" dan dalam bahasa Belanda disebut" Mensen rechten".Dalam bahasa Indonesia diterjemahkan dengan" hakhak kemanusiaan" atau" hak asasi manusia" (Dardji, 1981: 80). Hak asasi manusia adalah hak-hak yang dimiliki oleh setiap manusia yang harus dinikmatinya semata-mata karena ia adalah manusia. Pada konferensi dunia tentang hak asasi manusia di wina tahun 1993 ditegaskan bahwa hak asasi manusia, adalah hak yang dibawa manusia sejak lahir dan bahwa perlindungan atas hak itu merupakan tanggungjawab Pemerintah. Hak asasi manusia didasarkan pada prinsip dasar bahwa semua orang mempunyai martabat kemanusiaan hakiki tanpa memandang jenis kelamin,ras, warna kulit,agama, bangsa dan keyakinan.

HAM (Hak Asasi Manusia), Hak dapat diartikan sebagai kekuasaan dalam melakukan sesuatu atau kepunyaan, sedangkan Asasi adalah hal yang utama, dasar. Sehingga hak asasi manusia atau sering disebut sebagai HAM dapat diartikan sebagai kepunyaan atau milik yang bersifat pokok dan melekat pada setiap insan sebagai anugerah yang telah diberikan oleh Allah swt. Hak Asasi Manusia adalah hak-hak yang sudah dipunyai oleh seseorang sejak ia masih dalam kandungan. Hak Asasi Manusia dapat berlaku secara universal. 
Sementara Hedley Bull, ilmuan politik Australia mendefenisikan Hak Asasi Manusia sebagai hak yang melekat pada diri manusia itu saja, bukan melekat pada golongan manusia ini dan itu (Mohammad Monib, 2011: 41-41). Hak Asasi Manusia dipandang dimiliki oleh segenap manusia secara adil. Thomas Paine dalam The Right of Man menulis "HAM itu adalah hak-hak yang dimiliki oleh seseorang karena keberadaannya. Diantara hak-hak seperti ini tercakup segala hak intelektual, atau hak berfikir, juga segala hak untuk bertindak sebagai individu demi kenyamanan dan kebahagiaan sendiri, asal tidak merugikan hak-hak asasi orang lain". Inilah beberapa defenisi atau pemahaman tentang makana HAM yang kita kenal dari banyak ilmuan.

Karena begitu sulitnya mendefinisikan HAM itu, sebagian cendikiawan mengacu pada hak yang dimiliki segenap manusia, dan hak itu memiliki statusnya sendiri. Hak asasi dipandang lebih penting dari pada semua hak lainnya, atas dasar inilah sehingga mengapa disebut Hak Asasi Manusia (HAM).

Bebicara tentang definisi HAM, kita akan dibenturkan dengan berbagai perspektif dan perbedaan konsepsi tentang manusia. Definisi tentang HAM modern lebih menekankan pada kedaulatan individu, otoritas mutlak perbuatan manusia, dan kebebasannya dari apapun termasuk dari intervensi Tuhan. Hak asasi manusia pada dasarnya bersifat umum atau universal karena diyakini bahwa beberapa hak yang dimiliki manusia tidak memiliki perbedaan atas bangsa, ras, atau jenis kelamin. Dasar hak asasi manusia adalah manusia berada dalam kedudukan yang sejajar dan memiliki kesempatan yang sama dalam berbagai macam aspek untuk mengembangkan potensi yang dimilikinya (Heri Herdianto, 2010: 64).

Hak asasi manusia pada dasarnya bersifat umum atau universal karena diyakini bahwa beberapa hak yang dimiliki manusia tidak memiliki perbedaan atas bangsa, ras, atau jenis kelamin. Dasar hak asasi manusia adalah manusia berada dalam kedudukan yang sejajar dan memiliki kesempatan yang sama dalam berbagai macam aspek untuk mengembangkan potensi yang dimilikinya. Salah satu Hak Asasi Manusia yang sifatnya universal penting untuk dilindungi adalah pelanggaran Hak Asasi Manusia dalam bentuk penganiayaan, penyiksaan dan penahanan secara sewenang-wenangan (Jumadi, 2012: 54).

Selanjutnya dalam konteks Negara kita, KOMNAS HAM Indonesia mendefenisikan HAM sebagai berikut "Hak asasi adalah hak yang melekat pada setiap 
manusia untuk dapat mempertahankan hidup, harkat, dan martabatnya. Pengembangan hak tersebut dilakukan secara seimbang antara hak dan kewajiban dan antara kepentingan perseorangan dan kepentingan umum.

Sejalan dengan amanat Konstitusi, Indonesia berpandangan bahwa pemajuan dan perlindungan HAM harus didasarkan pada prinsip bahwa hak-hak sipil, politik, ekonomi, sosial budaya dan hak pembangunan merupakan satu kesatuan yang tidak dapat dipisahkan, baik dalam penerapan, pemantauan, maupun pelaksanaannya.

Jadi, mengenai definisi HAM sampai saat ini belum ada consensus atau batasan pengertian yang disepakati secara universal. Belum ada definisi yang mencakup karakter manusia dari barat sampai timur, selatan sampai utara. Namun demikian, masyarakat dunia menyepakati bahwa rumusan-rumusan HAM dalam deklarasi HAM PBB dan seluruh komvonen, traktat dan perjanjian internasional lain yang menyertainya, adalah merupakan standar patokan standar pengakuan hak-hak manusia dan acauan normatif moral politik penegakan HAM di seluruh dunia.

\section{Studi Perbandingan Hukum Rajam Dalam Islam dan Hukum Nasional}

Pandangan diantara para fuqaha tentang hukuman rajam Hukum rajam adalah sangsi hukum yang dianggap tidak berprikemanusiaan oleh kalangan masyarakat, karena bertujuan untuk menghilangkan nyawa seseorang, dengan jalan melemparinya dengan batu sampai mati. Eksekusi ini dijatuhkan kepada pelaku zina muhsan, baik laki-laki maupun perempuan. Seorang pelaku zina mu.h.san yaitu: seorang mukallaf, berakal, waras, baligh. Ia adalah seorang yang merdeka bukan hamba sahaya, dan ia sudah terikat dalam perkawinan atau sudah pernah merasakan persetubuhan dalam ikatan perkawinan. Hukum rajam memang tidak tercantum dalam al-Qur'an, akan tetapi sebagian fuqaha' setuju dengan hukuman rajam, dengan dasar hadis Nabi sebagai sandaran hukum. Namun sebagian Fuqaha' yang lain menyatakan tidak setuju dengan hukuman rajam, karena mereka mengganggap bahwa hadis tersebut tidak cukup sebagai dasar hukum. Oleh karena itu hukuman rajam menjadi pro dan kontra dikalangan fuqaha'. Sebagian fuqaha' yang tidak setuju dengan hukuman rajam adalah khawarij, sebagian ulama'Syi'ah dan sebagian mu'tazilah (Umar Shihab, 2005: 438). 
Munculnya perbedaan pandangan terhadap hukuman rajam berpangkal pada: pertama, perbedaan pemahaman atas kandungan hukum pada QS An-Nur ayat 2. Kedua, perbedaan penilaian terhadap sah dan tidaknya penetapan hukuman rajam berdasarkan hadis yang tidak kuat. Ketiga, keyakinan oleh sementara pihak yang berpendapat bahwa hukuman rajam pernah diterapkan oleh Nabi adalah terjadi sebelum turunnya QS An-Nur ayat 2, dan sanksi rajam tersebut tidak berlaku lagi setelah turunnya QS An-Nur ayat 2.

1. Ulama yang Setuju dengan Pemberlakuan Hukum Rajam

Para ulama sepakat bahwa orang yang telah berzina dan tergolong sebagai zina muhshan maka harus dihukum rajam, terutama al-mazahib al-arba'ah (mazhab yang empat) yaitu mazhab hanafi, maliki, syafi'I dan hambali. Dalam Al-qur'an ayat rajam tidak tercantum, namun seperti apa yang telah dibahas di atas dalam kandungan nash Al-qur'an mengenai rajam, sejumlah kitab fiqhi telah menjelaskan bahwa pada mulanya ayat rajam termaktub dalam Al-qur'an, dalam perkembangannya ayat itu dihapuskan namun hukumnya tetap berlaku (naskh alrasm wa baqa' al-hukum) yaitu lafadznya ditiadakan namun hukumnya tetap di berlakukan (Kulliyat, 1998: 76). Menurut Khalifah Umar bin Khattab bahwasanya dulu ada ayat yang pernah diturunkan yang artinya sebagai berikut (Zainuddin Ali, 2007: 47):

"Laki-laki tua yang berzina dan perempuan tua yang berzina, maka rajamlah secara sekaligus, sebagai balasan dari Allah".

Hal ini ditambhakan oleh An-Nasa'I dalam buku Muhammad Abduh Malik bahwasanya ayat tersebut tepatnya berada dalam surat Al-Ahzab, kemudian dalam AlMuattha juga mencantumkan hadist itu bersumber dari Yahya bin Said dari Ibnu Musayyad. Ayat dan beberapa hadis yang menjadi pegangan para ulama yang sepakat terhadap pemberlakuan hukum rajam. Sedangkan dasar hukuman rajam yang berasal dari sunnah, maka ada riwayat mutawatir dari Rasulullah saw baik perkataan maupun perbuatan yang menerangkan bahwa Rasulullah saw telah merajam pezina yang mu.h.san.

Berdasarkan dalil-dalil tersebut dan sejarah pemberlakuannya sampai masa wafatnya Rasulullah saw hukum rajam masih tetap diberlakukan dan dilestarikan sampai pada masa Khalifah Ali bin abi Thalib dan seterusnya, maka dengan adanya sunnah nabawiyyah dan atsar dari para sahabat maka ulama beserta jumhur sepakat 
bahwasannya hukum rajam adalah perintah Allah dan Rasulnya, yang di mana ini adalah bagian dari syariat Islam yang memang harus dipertahankan. Senada dengan apa yang di sampaikan di atas bahwasanya walaupun ayat terkait masalah hukum rajam tidak kita temukan dalam Al-qur'an namun dahulu ayat tersebut pernah ada.

2. Ulama yang Tidak Setuju dengan Pemberlakuan Hukum Rajam

Golongan Khawarij dan Mu'tazilah berpendapat bahwasannya ayat ataupun hadist terkait masalah hukuman bagi pelaku zina mmuhshan yaitu rajam telah dihapuskan oleh ayat QS Annur ayat 2, yaitu:

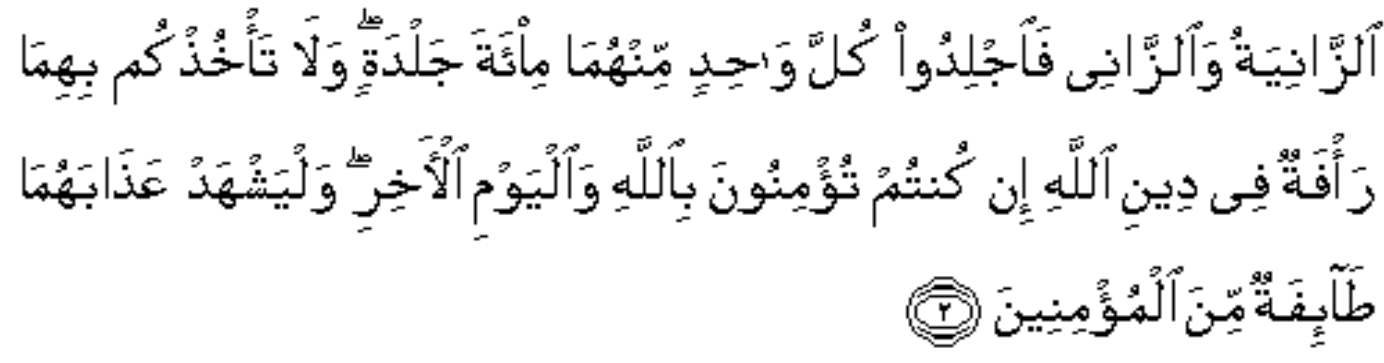

Artinya: Perempuan yang berzina dan laki-laki yang berzina, maka deralah tiap- tiap seorang dari keduanya seratus dali dera, dan janganlah belas kasihan kepada keduanya mencegah kamu untuk (menjalankan) agama Allah, jika kamu beriman kepada Allah, dan hari akhirat, dan hendaklah (pelaksanaan) hukuman mereka disaksikan oleh sekumpulan orang-orang yang beriman.

Memang Al-qur'an tidak membedakan antara pezina yang tergolong ghair muhshan dan muhshan. Pertimbangan ini sekalipun ia hadir dengan argumentasi yang dipertimbangkan oleh kaum Khawarij dan Azariqah sebagai salah satu argumentasi untuk menolak pemberlakuan hukum rajam (Ahmad Wardi Muslich, 2005: 35).

Dapat dikatakan pendapat kelompok ini bahwa ayat rajam terkait dengan sanksi hukum seperti rajam merupakan fiqhi jinayat Al-qur'an yang pada tingkat pelaksanaannya tidak otomatis bias dijalankan, dalam artian ummat Islam boleh mencari sanksi-sanksi hukum yang paling mungkin dan efektif untuk bagaimana bias membuat jerah para pelaku criminal. Bias dengan cara memenjarakan atau yang lainnya. Ibnu zaid pernah mengusulkan agar bagaimana orang yang telah melakukan perzinahan dilarang menikah sampai yang berzina meninggal dunia.

Sebagian ulama, seperti Muhammad Syahrur, berpandangan bahwa hukum potong tangan dan rajam merupakan hukuman maksimal al-hadd al-a'la yang hanya 
biasa dijalankan ketikan sanksi hukum yang lain tidak lagi efektif untuk mengurangi tingkat kriminalitas.

Dengan memperlakukan ayat-ayat jinayat sebagai fiqhi Al-qur'an, maka kaum golongan kedua yang di mana tidak setuju dengan pemberlakuan hukuman rajam berpendapat untuk bagaimana tidak lagi terikat supaya memaksakan penerapan sanksisanksi hukum itu seperti secara harfiah disebutkan dalam Alqur'an. Maka dapat mencari jenis-jenis hukuman yang lain yang lebih relevan dan sesuai dengan konteks keindonesian. Yang penting tujuan dari sanksi-sanksi hukum Islam untuk bagaimana bias membuat jera para pelaku tindak pidana sudah tercapai.

\section{Analisis Perbandingan Terhadap Hukum Rajam}

1. Rajam Dalam Perspektif Hukum Islam

Hukuman, di dalam hukum Islam, didasarkan atas tiga sistem; yaitu hudûd, ta'zir, dan qishâsh. Khusus berkenaan dengan hukuman-hukuman yang ditentukan (hudud) terdiri dari pemotongan tangan para pencuri, pecambukan karena menuduh wanita baik-baik berzina, pecambukan bagi pezina, dan pemenjaraan atau hukuman mati bagi perampok. Menurut Muhammad Sa'id al-Asymawi, ini semua adalah hukuman bersyarat yakni, hukuman-hukuman itu tidak akan diberlakukan kecuali jika syarat-syarat umum dan khusus telah terpenuhi. Syarat umum untuk menerapkan hukum tersebut berupa sebuah masyarakat beriman.

Dalam masyarakat tersebut, kita hanya membutuhkan pelaksanaan, saksi-saksi, dan hakim sehingga hukuman akan diterapkan dengan cara yang benar, ketimbang digunakan untuk mendukung atau melawan seseorang, atau di bawah tekanan pemerintah atau atas permintaan penguasa.

Hukuman berzina dalam Al-qur'an sebagai hukuman yang ditetapkan syara' adalah 100 kali cambukan bagi pezina laki-laki dan perempuan. Sedangkan hukuman rajam pertama kali dilakukan oleh nabi Muhammad saw berdasarkan ketentuan yang terdapat di dalam kitab Taurat, sebab dua orang yang dihukum rajam tersebut berasal dari orang Yahudi Madinah. Ada pendapat yang mengatakan bahwa hukum rajam berasal dari ayat yang terdapat pada surat al-Ahzab yang menyatakan bahwa seorang nenek dan kakek yang berzina dikenakan rajam sebagai ketentuan dari Allah. Namun, 
menurut mereka, teks ayat tersebut telah di-nasakh (dihapus) lafalnya dari Al-qur'an, sedangkan ketetapan hukumnya tetap berlaku. Pendapat itu menegaskan, seharusnya dalam Islam tidak ada nash yang dihapus yang kandungan hukumnya masih berlaku, terlebih ayat tentang rajam merupakan sesuatu yang krusial.

Keberadaan hukum rajam dalam Islam, salah satu di antaranya, didasarkan pada hadits Umar bin Khathab ra. di mana beliau dalam suatu kesempatan pernah berpidato: Sesungguhnya Allah swt telah mengutus Muhammad saw dengan kebenaran dan telah menurunkan padanya Al-Kitab (Al-qur'an). Maka terdapat ayat rajam pada apa yang diturunkan itu. Kami membacanya, menghafalnya, dan memahaminya.

Oleh karena Rasul pernah merajam kami pun merajam sesudahnya. Khawatir jika telah berlalu zaman, akan muncul orang yang mengatakan bahwa kami tidak menemukan rajam dalam kitab Allah. Sesungguhnya rajam itu hak (kebenaran) dalam kitab Allah atas orang yang berbuat zina, baik itu laki-laki maupun perempuan, jika muhshan dan adanya bukti, atau hamil, ataupun pengakuan.” Menyikapi pernyataan Umar di atas, ada beberapa kemungkinan interpretasi yang dapat diberikan. Pertama, bahwa hukum rajam itu ada dalam ajaran Islam. Rasulullah maupun khalifah Umar sendiri pernah menerapkan hukum rajam itu. Kekhawatiran Umar terhadap kemungkinan adanya pendapat yang meragukan keberadaan hukum rajam itu merupakan indikasi yang kuat bahwa hukum rajam itu ada dan terus berlaku sepanjang zaman. Agaknya pendapat inilah yang dipegang oleh jumhur ulama. Kedua, bahwa memang benar hukum rajam itu pernah ada dalam ajaran Islam dan baik Rasul maupun Umar sendiri pernah melakukannya (Mahmud syaltut, 1966: 12).

Akan tetapi hal itu tidak secara otomatis bahwa hukum rajam itu berlaku terusmenerus sepanjang zaman. Kekhawatiran Umar tersebut harus dipahami dalam konteks pernah adanya ayat dan hukum rajam itu dalam al-Qur'an yang kemudian dinasakh. Dan bentuk penasakhan ayat rajam ini sendiri ternyata masih menjadi perdebatan dikalangan ulama. Ada ulama yang mengatakan bahwa sungguh pun ayatnya telah dinasakh akan tetapi hukumnya tetap berlaku. Adapula ulama yang tidak setuju dengan pendapat seperti ini. Ketidak setujuan mereka itu karena informasi-informasi yang menjelaskannya adalah hadits-hadits ahad. 
Dalam hal memastikan atas turunnya ayat Al-qur'an beserta nasakhnya tidak dibenarkan dengan menggunakan hadis ahad. Ada pendapat yang mengatakan bahwa ayat dan hukum itu harus bersifat talazzum (tetap), karena ayat sebagai dalil adanya hukum. Maka ketika ayat tersebut dinasakh, hukumnya pun berarti dinasakh, dan jika tidak maka manusia tetap akan dibawa dalam kebingunan. Dan jika pendapat ini disetujui berarti hukum rajam itu telah dihapuskan oleh Al-qur'an sendiri. Penjelasan di atas menunjukkan bahwa keberadaan ayat rajam dalam bentuk bacaannya dihapuskan akan tetapi hukumnya masih menjadi perdebatan di kalangan ulama.

Tentu saja bagi ulama yang setuju dan mengakuinya akan tetap menerapkan hukum rajam, dan demikian pula sebaliknya. Kenyataan ini menunjukkan pula bahwa dilihat dari perspektif ini, hukum rajam masih bersifat zhanni, padahal hukuman hudud harus bersifat qath'I (Yahya, 1986: 45).

Oleh sebab itu hal ini masih bisa diperdebatkan. Jika kemudian dinyatakan bahwa hukum rajam itu ditetapkan oleh hadits-hadits, maka persoalan yang muncul kemudian apakah hadits-hadits yang berhubungan dengan hukum rajam itu dikemukakan sebelum ayat rajam itu dinasakh atau sesudahnya.

\section{Rajam Dalam Perspektif Hukum Nasional}

Dalam hukum nasional sangat jelas perbedaan antara hukum Islam dan hukum yang berlaku saat ini di Indonesia khususnya berkaitan dengan sanksi bagi pelaku zina muhshan, Menurut KUHP tidak semua pelaku zina diancam dengan hukuman pidana. Misalnya pasal 284 ayat (1) dan (2) menetapkan ancaman pidana penjara paling lama 9 bulan bagi pria dan wanita yang melakukan zina, padahal seorang atau keduanya telah kawin, dan dalam pasal 27 KUH Perdata (BW) berlaku baginya.

Ini bisa diartikan bahwa pria dan wanita yang telah melakukan zina dan belum kawin, maka mereka tidak terkena sanksi hukuman tersebut di atas. Dan tidak pula dapat dikenakan hukuman bagi keduanya asalkan telah dewasa dan suka sama suka (tidak ada unsur paksaan), kecuali dengan wanitanya yang belum dewasa dapat dikenakan sanksi, hal ini diatur dalam KUHP pasal 285 dan 287 ayat (1). Sedangkan menurut hukum pidana Islam, semua pelaku zina pria dan wanita dapat dikenakan had, yaitu hukuman dera bagi yang belum kawin, dengan catatan bahwasannya dera ini tidak boleh berakibat fatal bagi yang dikenai hukuman. 
Selanjutnya dalam KUHP, perbuatan zina hanya dapat dituntut atas pengaduan suami maupun istri yang tercemar (pasal 284 ayat 2), sedangkan Islam tidak memandang zina sebagai klach delict (hanya bisa dituntut) atas pengaduan yang bersangkutan. Hukum positif KUHP dalam menyikapi masalah perzinahan, ada berbagai variasi hukuman (klasifikasi). Dengan penerapan hukuman yang berbeda-beda yang tertuang dalam KUHP pasal 284 ayat (1) dan (2), pasal 285, 286 dan 287 ayat (1). Sedangkan dalam Islam itu sendiri menetapkan hukuman dera jika pelaku zina yang belum kawin dan hukuman rajam jika telah kawin (muhshan).

\section{Pandangan HAM Terhadap Hukum Rajam}

Bagi banyak negara larangan penyiksaan itu sendiri dapat diterima, ada diskusi yang di mana masih berlangsung tentang lingkup defenisi penyiksaan itu sendiri, untuk beberapa negara terdapat sebuah hirarki latin yang memandang penyiksaan merupakan tindakan yang paling keji dan tunduk pada larangan mutlak, sementara itu adalah bagian dari suatu perlakuan yang tidak manusiawi dan merendahkan martabat.

Di dalam regional pada mulanya tampak keengganan untuk mengutuk kegiatan negara sebagai penyiksaan dengan alasan politik dan diplomatik, perbuatan yang tidak manusiawi dan merendahkan martabat seringkali lebih disukai.

Adapun kandungan tentang larangan penyiksaan atau perlakuan hukuman yang lain dan kejam, tidak manusiawi atau merendahkan martabat terdapat dalam pasal-pasal berikut:

Pasal 7 DUHAM yang berisi (Ahmad Kosasih, 2003: 183):

“Tidak seorang pun dapat dikenai penyiksaan, atau perlakuan atau hukuman lain yang kejam, tidak manusiawi atau merendahkan martabat khususnya, tidak seorang pun dapat dijadikan objek eksperiment medis atau ilmiah tanpa persetujuannya".

Larangan atas penyiksaan cukup mapan dan dianggap sebagai norma mutlak hukum internasional. Konvenant internasional tentang hak sipil dan politik tidak mendefenisikannya penyiksaan, tetapi pasal 1 ayat (1) konvensi menentang penyiksaan dan bentuk perlakuan dan hukuman lainnya yang kejam, tidak manusiawi, dan merendahkan martabat.

Ketentuan hukuman rajam berlawanan antara lain dengan:

1. Deklarasi Umum HAM (DUHAM). 
2. Konvensi menentang penyiksaan dan perlakuan atau penghukuman lain yang kejam, tidak manusiawi dan merendahkan martabat manusia.

3. Konvensi Hak Sipil dan Politik dan UUD 1945

Ancaman hukuman rajam dengan apa yang ada diatas, apabila kemudian dieksekusi maka akan mengakibatkan sebuah masalah dalam hal bahwa eksekusi itu harus berakibat kepada pelukaan dan menyiksa, dan kemudian dilakukan dengan cara-cara yang tidak semua orang mungkin akan mampu melihatnya pada situasi di masa kini. Sedangkan hukuman mati berlawanan dengan DUHAM menyatakan:

1. Hak hidup adalah hak asasi (Pasal 3 DUHAM: setiap orang berhak atas kehidupan, kebebasan dan keselamatan sebagai individu).

2. Hak hidup sebgai hak asasi juga disebutkan dalam konvensi Hak Sipil dan Politik (pasal 6: setiap manusia berhak atas hak untuk hidup yang melekat pada dirinya. Hak ini wajib untuk dilindungi oleh hukum, dan tidak seorangpun dapat dirampas hak hidupnya secara sewenang-wenang).

3. Dalam UUD 1945, hak untuk hidup juga diakui (pasal 28A: setiap orang berhak untuk hidup serta berhak untuk mempertahankan hidup dan kehidupannya, kemudian dalam pasal 28I: hak untuk hidup, hak untuk tidak disiksa, adalah hak asasi yang tidak dapat dikurangi dalam keadaan apapun).

PBB juga telah mengeluarkan protokol tambahan tentang penghapusan hukuman mati namun meskipun Indonesia sudah mengadopsi Konvenan Hak Sipil dan Politik, Indonesia tidak turut meratifikasi protocol tersebut, karena beberapa UU masih mencantumkan hukuman mati. Di samping itu, hukuman mati juga dilarang dalam konvensi eropa untuk bagaimana dijadikan sebagai perlindungan HAM dan kebebasan mendasar dalam statuta Roma tentang International Criminal Court, yang di mana juga bersumber dari nilai-nilai yang diakui secara internasioal (Ian Brownlie, 1993: 77).

Sampai sekarang penjatuhan hukuman mati masih tetap menjadi suatu hal begitu controversial, melanggar HAM dan karena itu banyak yang menentangnya, sudah ada beberapa negara yang telah menghapus hukuman mati, namun ternyata masih banyak pula negara yang mencantumkan hukuman mati dalam UU mereka. Seluruh negara di Benua Eropa telah menghapus hukuman mati. Namun di Amerika Serikat beberapa negara bagian 
masih menerapkan hukuman mati. Hukuman mati juga diterapkan di Malaysia, Singapura, Vietnam, Indonesia, Jepang, Arab dan lain-lain.

Di Indonesia dikenakan terhadap pelaku kejahatan jenis tertentu seperti terorisme, narkotika dan pembunuhan berencana. Eksekusi hukaman mati di Indonesia dilakukan dengan cara menembak terhukum sampai mati. Karena dianggap melanggar UUD 1945 yang di mana mengakui hak untuk sebagai hak asasi, maka pernah dilakukan judicial review terhadap ancaman hukuman mati dalam UU narkotika. Namun Mahkamah Konstitusi mengatakan bahwa hukuman mati di Indonesia tidak melanggar konstitusi sebab hukuman itu ditujukan untuk menghormati hak orang lain.

\section{PENUTUP}

Berdasar atas pembahasan sebagaimana telah diuraikan di atas maka dapat ditarik kesimpulan sebagai berikut:

1. Adanya perbedaan pandangan terhadap hukuman rajam oleh para fuqaha berpangkal pada: pertama, perbedaan pemahaman atas kandungan hukum pada QS An-Nur ayat 2. Kedua, perbedaan penilaian terhadap sah dan tidaknya penetapan hukuman rajam berdasarkan hadis yang tidak kuat. Ketiga, keyakinan oleh sementara pihak yang berpendapat bahwa hukuman rajam pernah diterapkan oleh Nabi adalah terjadi sebelum turunnya QS An-Nur ayat 2, dan sanksi rajam tersebut tidak berlaku lagi setelah turunnya QS An-Nur ayat 2.

2. Dalam perspektif hukum Islam, didasarkan atas tiga sistem hukum; yaitu hudûd, ta'zir, dan qishâsh. Keberadaan hukum rajam dalam Islam, salah satu di antaranya, didasarkan pada hadits Umar bin Khathab ra. Dalam hukum nasional terlihat jelas perbedaan antara hukum Islam dan hukum yang berlaku saat ini di Indonesia khususnya berkaitan dengan sanksi bagi pelaku zina muhshan.

3. Pandangan HAM terhadap hukuman rajam adalah ketentuan hukuman rajam berlawanan antara lain dengan: Deklarasi Umum HAM (DUHAM), Konvensi menentang penyiksaan dan perlakuan atau penghukuman lain yang kejam, tidak manusiawi dan merendahkan martabat manusia, dan Konvensi Hak Sipil dan Politik dan UUD 1945. 


\section{DAFTAR PUSTAKA}

\section{Buku:}

Ahmad Kosasih, HAM dalam Perspektif Islam Menyikapi Persamaan dan Perbedaan antara Islam dan Barat, Salembah Diniyah, Jakarta, 2003.

Ahmad Wardi Muslich, Hukum Pidana Islam, Sinar Grafika, Jakarta 2005.

Dardji Darmodiharjo dkk. Santiaji Pancasila, Usaha Nasional, Surabaya, 1981.

Departemen Agama RI, Al-Qur'an dan Terjemahnya, CV. Pustaka Assalam, Surabaya, 2010.

Heri Herdianto, Cerdas, Kritis, dan Aktif Berwarganegara, PT. Gelora Aksara Pratama, Jakarta, 2010.

Ian Brownlie, Dokumen- Dokumen Pokok Mengenai Hak Asasi Manusia, UI Press, Jakarta, 1993.

Jumadi, Refleksi Hak Asasi Manusia di Indonesia, Alauddin University press, Makasar, 2012.

Kulliyat Al-Mu'allimin Al-Islamiah, Al-bayan fi 'Ilmi Ushul al-Fiqh, Darussalam Press, Ponorogo, 1998.

Mahmud syaltut, Al- Islam 'aqidah wa syari'ah, Dar al-Qalam, Mesir, 1966.

Mohammad Monib, Islah Bahrawi, Islam dan Hak Asasi Manusia Dalam Pandangan Nurcholis Majid, PT Gramedia Pustaka Utama, Jakarta, 2011.

Topo Santoso, Membumikan Hukum Pidana Islam, Penerbit Gema Insani , Jakarta, 2003.

Umar Shihab, Kontekstualisasi Al Qur'an Kajian Tematik Atas Ayat-Ayat Hukum Dalam Al Qur'an, Penamadani, Jakarta, 2005.

Yahya, Mukhtar, Dasar-dasar Pembinaan Hukum Fiqh Islam, Al-Ma'arif, Bandung, 1986.

Zainuddin Ali, Hukum Pidana Islam, Sinar Grafika, Jakarta, 2007.

\section{Website:}

woocara,http://woocara.blogspot.com/2015/10/pengertian-ham-macam-macamhamcontoh-pelanggaran-ham.html\#ixzz4HVg9FlVd. Akses 6 Desember 2019. 